\title{
Common Genetic Variants in the Complement System and their Potential Link with Disease Susceptibility and Outcome of Invasive Bacterial Infection
}

\author{
Bryan van den Broek ${ }^{a, c, d}$ Michiel van der Flier ${ }^{a-d}$ Ronald de Groot ${ }^{c, d}$ \\ Marien I. de Jonge ${ }^{c, d}$ Jeroen D. Langereis ${ }^{c, d}$ \\ a Paediatric Infectious Diseases and Immunology, Amalia Children's Hospital, Nijmegen, The Netherlands; \\ ${ }^{b}$ Expertise Center for Immunodeficiency and Auto inflammation (REIA), Radboudumc, Nijmegen, The Netherlands; \\ 'Section Paediatric Infectious Diseases, Laboratory of Medical Immunology, Radboud Institute for

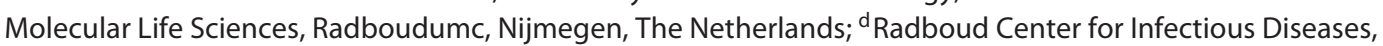 \\ Radboudumc, Nijmegen, The Netherlands
}

\section{Keywords}

Complement system $\cdot$ Common genetic variants $\cdot$ Single nucleotide polymorphisms . Disease susceptibility .

Inflammation · Streptococcus pneumoniae

\begin{abstract}
Streptococcus pneumoniae and Neisseria meningitidis are pathogens that frequently colonize the nasopharynx in an asymptomatic manner but are also a cause of invasive bacterial infections mainly in young children. The complement system plays a crucial role in humoral immunity, complementing the ability of antibodies to clear microbes, thereby protecting the host against bacterial infections, including $S$. pneumoniae and $N$. meningitidis. While it is widely accepted that complement deficiencies due to rare genetic variants increase the risk for invasive bacterial infection, not much is known about the common genetic variants in the complement system in relation to disease susceptibility. In this review, we provide an overview of the effects of common genetic variants on complement activation and on complement-mediated inflammation.

(C) 2019 The Author(s)

Published by S. Karger AG, Basel
\end{abstract}

\section{Introduction}

The complement system has an essential role in the protection against invading bacterial pathogens, which is clearly illustrated in patients with complement deficiencies who have an increased risk to develop invasive bacterial infections [1]. On the other hand, the development of complement evasion mechanisms by human pathogens to enable prolonged persistence also highlight the important role for complement in the eradication of bacterial pathogens [2]. However, besides mutations causing complement deficiencies, common single nucleotide polymorphisms (SNP) and combinations thereof, also named the "complotype," can potentially have a role in disease susceptibility [3]. The aim of this review is to provide an overview of the effects of common SNPs in the complement system on complement activation, Toll-like receptor (TLR) crosstalk, and the interindividual differences in susceptibility for infection with Streptococcus pneumoniae and Neisseria meningitidis used as examples. We will give a short overview regarding pathogen immune evasion mechanisms and host complement deficiencies leading to susceptibility for infections by these pathogens. Finally, we will give our view

\begin{tabular}{|c|c|}
\hline KARGER & $\begin{array}{l}\text { (c) } 2019 \text { The Author(s) } \\
\text { Published by S. Karger AG, Basel }\end{array}$ \\
\hline $\begin{array}{l}\text { E-Mail karger@karger.com } \\
\text { www.karger.com/jin }\end{array}$ & $\begin{array}{l}\text { This article is licensed under the Creative Commons Attribution- } \\
\text { NonCommercial-NoDerivatives } 4.0 \text { International License (CC BY- } \\
\text { NC-ND) (http://www.karger.com/Services/OpenAccessLicense). } \\
\text { Usage and distribution for commercial purposes as well as any dis- } \\
\text { tribution of modified material requires written permission. }\end{array}$ \\
\hline
\end{tabular}

Dr. Jeroen D. Langereis

Radboudumc, Laboratory of Medical Immunology Section of Pediatric Infectious Diseases and Immunology, Route 412

PO Box 9101, NL-6500 HB Nijmegen (The Netherlands)

E-Mail jeroen.langereis@ radboudumc.nl 
on the potential role of common genetic variants of the complement system in disease susceptibility for Gramnegative ( $N$. meningitidis) and Gram-positive bacteria ( $S$. pneumoniae and Streptococcus pyogenes).

\section{Pneumococcal Disease}

Streptococcus pneumoniae, or the pneumococcus, is an encapsulated Gram-positive bacterium and a micro-aerophilic member of the genus Streptococcus that typically grows in pairs or short chains [4]. The polysaccharide capsule is the most important virulence factor of $S$. pneumoni$a e$, and based on differences in the composition of the capsule, this bacterium is classified into over 95 serotypes $[5,6]$.

S. pneumoniae is transmitted via droplets and aerosols to the upper respiratory tract initiating asymptomatic carriage in the nasopharynx, also described as colonization. The highest carriage rates of $S$. pneumoniae in the nasopharynx are found in preschool children and can be as high as $60 \%$ [7]. In colonized children, often in conjunction with a viral infection, the pneumococcus can migrate to the middle ear where it can cause otitis media or to the lungs where it can cause pneumonia. S. pneumoniae can also cross the respiratory epithelium and cause invasive infections in the blood and cerebrospinal fluid leading to sepsis and meningitidis [8].

Pneumococcal infections can be effectively treated with antibiotics. Several antibiotic classes, mainly betalactams and macrolides, are used to treat pneumococcal infections. However, resistance is increasing in many parts of the world [9-11].

Polysaccharide-based vaccines are used to prevent pneumococcal disease. These vaccines evoke antibodies that activate the classical complement pathway that, in conjunction with the alternative pathway (AP), is important for complement-dependent protection against S. pneumoniae infections [12].

\section{Meningococcal Disease}

Neisseria meningitidis, or the "meningococcus", is a Gram-negative diplococcus and an obligate human pathogen. The capsule is the main virulence factor and can be classified into 13 different serotypes of which 6 serotypes (A, B, C, W135, X, and Y) are responsible for most meningococcal infections $[13,14]$.

This bacterium is transmitted through respiratory droplets and close contacts [15]. On average, $10 \%$ of the population is asymptomatically colonized by the meningococcus in the nasopharynx, which peaks at $23 \%$ in adolescent and young adults, but can be up to $70 \%$ in crowded settings $[14,16,17]$. In about 1 per 100,000 inhabitants in Europe, the meningococcus can migrate to the bloodstream and/or the cerebral spinal fluid causing invasive meningococcal disease (IMD).

Similar to pneumococcal vaccines, meningococcal vaccination-induced antibodies activate the classical complement pathway that, in conjunction with the AP, is important in protection against $N$. meningitidis infections $[18,19]$.

\section{Complement Evasion Mechanisms}

During colonization and invasion, bacterial pathogens are exposed to the bactericidal activity of the complement system. As a result of this selective pressure, bacterial pathogens have developed mechanisms to evade this antimicrobial activity, highlighting that alterations in complement activity can tip the balance toward an advantage for the pathogen. A complete overview on S. pneumoniae complement evasion mechanisms has recently been summarized by Andre et al. [20]. Here, we have highlighted a few key mechanisms as examples (Fig. 1).

The polysaccharide capsule is a major virulence factor that limits binding of complement on the pneumococcal surface and prevents interaction of surface-bound complement with receptors on host cells. Furthermore, the capsule inhibits binding of C-reactive protein (CRP), which is important for initiating complement deposition on the bacterial surface [21].

Next to the capsule, S. pneumoniae expresses multiple proteins that bind human complement regulatory proteins such as factor $\mathrm{H}$ and $\mathrm{C} 4$ binding protein [22-24], whereas others prevent binding of, for instance, CRP and factor B $[25,26]$. Secretion of pneumolysin is thought to result in systemic complement activation and consumption, thereby preventing complement deposition to the bacterial surface $[27,28]$. There are multiple pneumococcal moonlighting proteins (endopeptidase, alpha-enolase, glyceraldehydes-3-phosphate dehydrogenase, phosphoglycerate kinase, and Elongation factor Tu (Tuf)) described that are able to bind plasminogen to cleave C3/ $\mathrm{C} 3 \mathrm{~b}$ to interfere with complement opsonization [29-33].

Similarly to $S$. pneumoniae, $N$. meningitidis also has a protective capsule and is able to bind factor $\mathrm{H}$ or $\mathrm{C} 4$ binding protein to its bacterial surface [34-36], thereby preventing complement activation. $\mathrm{NalP}$ is a serine protease 


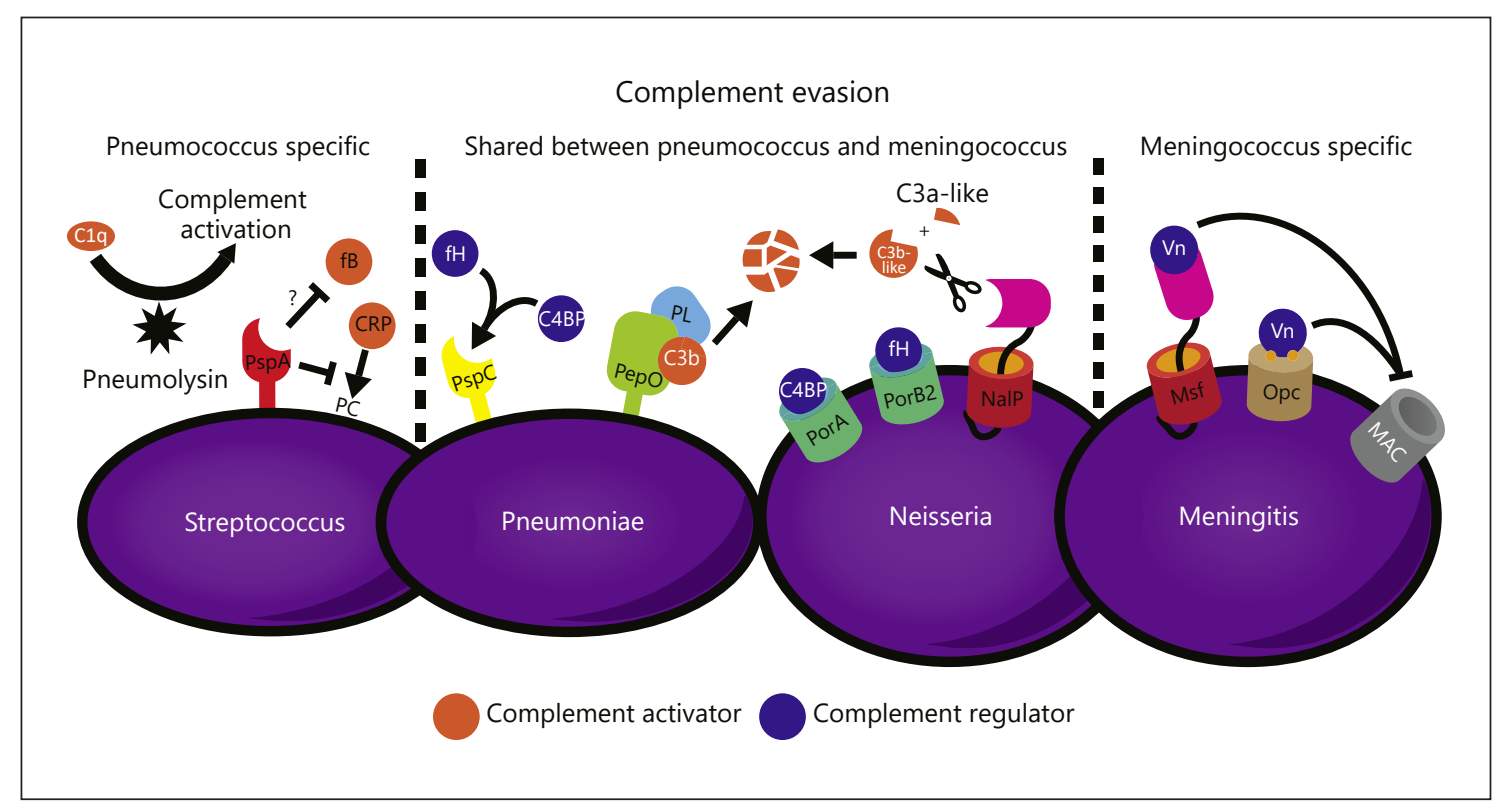

Fig. 1. Some complement evasion proteins from Streptococcus pneumoniae and Neisseria meningitidis. Both $S$. pneumoniae and N. meningitidis use complement evasion mechanisms to circumvent opsonization (and killing) by the complement system. Both pathogens use similar mechanisms and different complement evasion mechanisms to counteract the complement system.

autotransporter that cleaves C3, 4 amino acids upstream of the normal cleavage site. This produces a shorter C3alike fragment and a longer C3b-like fragment that is degraded, resulting in a lower deposition on the bacterial surface [37].

In addition, $N$. meningitidis has strategies that prevent insertion of the membrane attack complex (MAC). Meningococcal surface fibril and outer membrane protein Opc have been identified as vitronectin binding proteins, which are a soluble complement regulator from the host that bind to C5b-7, thereby preventing insertion of the complex into the bacterial membrane $[38,39]$.

\section{The Complement System}

As mentioned above, bacterial pathogens are able to prevent complement activation through various routes, but how is human complement activated and regulated. The complement system is an essential innate immune surveillance system forming an important line of defense against invading microbes [40]. The complement system consists of 3 different pathways of activation: the classical pathway (CP), the lectin pathway (LP), and the AP (Fig. 2). Activation of one of these pathways leads to op- sonization of the bacterium with $\mathrm{C} 3 \mathrm{~b}$ for phagocytosis, release of anaphylatoxin $\mathrm{C} 3 \mathrm{a}$ and chemo-attractant $\mathrm{C} 5 \mathrm{a}$, and lysis of Gram-negative bacteria through the MAC, called the terminal pathway (TP).

The $\mathrm{CP}$ is activated by $\mathrm{Clq}$ binding to mainly CRP, IgM, or IgG bound to the bacterial surface [41]. Once activated, CP C3 convertase C4b2a is formed, which cleaves C3 into C3a and C3b [40]. The LP C3 convertase is similar to the CP C3 convertase, although activation of the LP starts when Mannan-binding lectin, ficolins, and/or collectin 11 recognize specific sugar patterns on the bacterial surface $[42,43]$. The AP can be activated spontaneously in fluid phase via hydrolysis of $\mathrm{C} 3$ to $\mathrm{C} 3\left(\mathrm{H}_{2} \mathrm{O}\right)$, a process known as tick-over [40]. Another important function of the AP is the amplification of $\mathrm{C} 3 \mathrm{~b}$ deposition via factor $\mathrm{B}$ that binds to $\mathrm{C} 3 \mathrm{~b}$ resulting in the formation of an AP C3 convertase C3bBb [40, 44].

Deposition of $\mathrm{C} 3 \mathrm{~b}$ on the bacterial surface is an important signal required for effective phagocytosis of the pathogen [40]. In addition, C3b can bind to C3 convertases leading to the formation of a C5 convertase that cleaves $\mathrm{C} 5$ into the chemoattractant $\mathrm{C} 5 \mathrm{a}$ and $\mathrm{C} 5 \mathrm{~b}$. $\mathrm{C} 5 \mathrm{~b}$ together with $\mathrm{C} 6, \mathrm{C} 7, \mathrm{C} 8$, and $\mathrm{C} 9$ form the $\mathrm{MAC}$ that can lyse specifically Gram-negative bacteria directly. 
Fig. 2. Schematic representation of the 3 different activation pathways of the complement system. Depicted are the complement components that contain either a deficiency and/or an SNP that is discussed in this review.

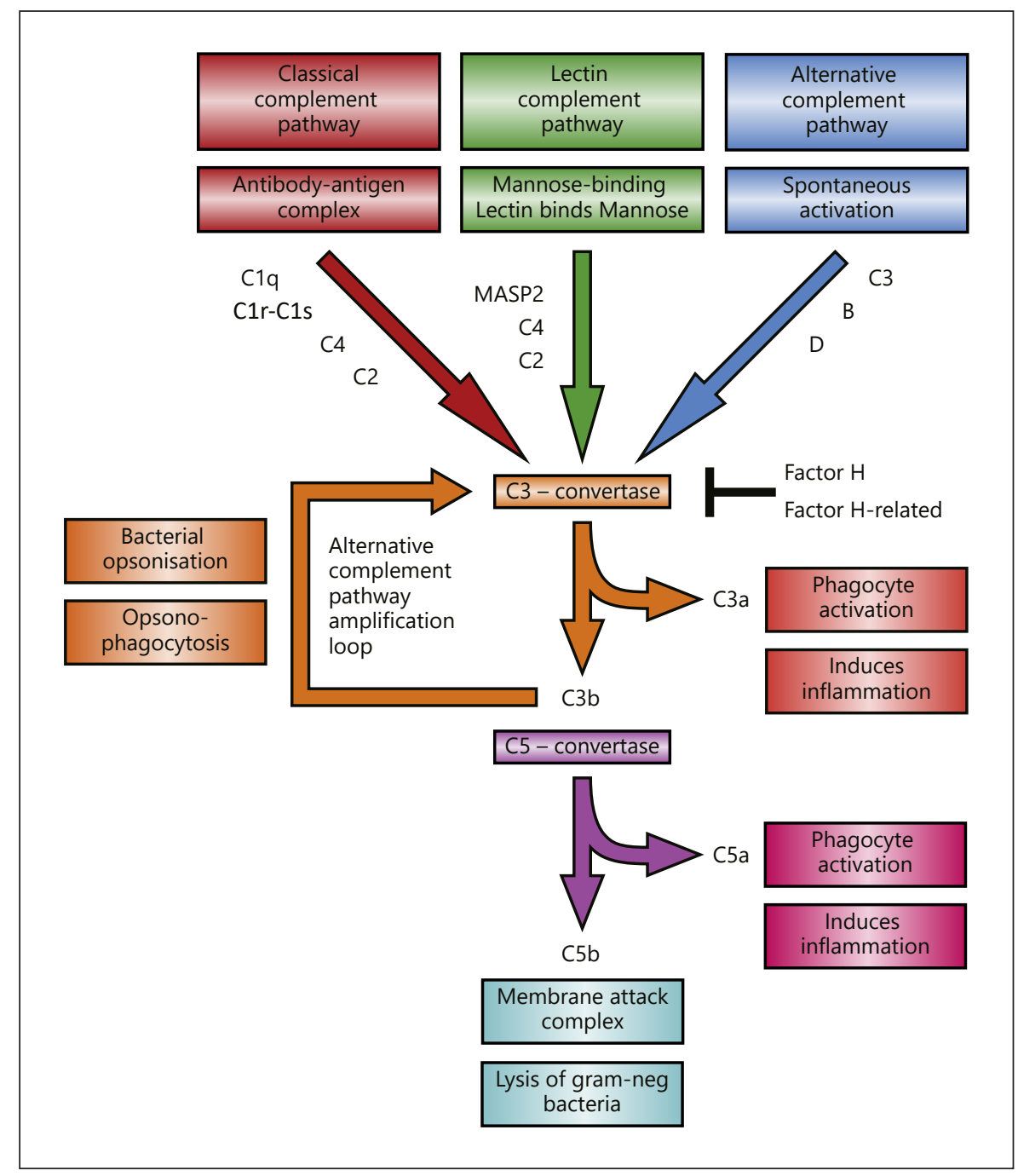

\section{TLRs and Complement}

Germline encoded pattern recognition receptors (PRRs) form another innate immune surveillance system for the initial detection of microbes. PRRs recognize microbe-specific molecular signatures known as pathogen-associated molecular patterns and autologous derived molecules from damaged cells, referred to as damage-associated molecular patterns [45]. The innate immune system has several classes of PRRs from which the TLRs are the best characterized. Activation of TLRs initiates downstream signaling, resulting in cytokine and chemokine production, essential to direct the immune response and for the recruitment of other immune cells to the side of infection [46]. S. pneumoniae mainly activates TLR 2 and TLR $4[47,48]$. It has earlier been described that there is crosstalk between the complement system and the TLR signaling [49].
In a recent study, it was shown that small differences in human factor $\mathrm{H}$ serum levels can have large effects on complement-dependent opsonophagocytic killing of $S$. pneumoniae [50] and cytokine release by peripheral blood mononuclear cells (PBMCs), which were dependent on TLR- and C5a-mediated costimulation [51].

\section{Rare Genetic Variants and Susceptibility to Pneumococcal and Meningococcal Disease}

SNPs in complement factors, such as C5 (rs17611) and C3 (rs2230199), can lead to reduced levels or function of complement factors. These genetic variants can potentially increase the risk of infection with bacterial pathogens and the risk for other diseases, such as autoimmune disease (e.g., systemic lupus erythematosus) and malig- 
nancies. In this review, we focus on the effect of rare genetic variants in complement and the susceptibility to bacterial diseases. For a more extensive overview of rare genetic variants in complement genes and their association with invasive bacterial infections, see recent review by Goicoechea de Jorge et al. [52].

Due to codominant expression, heterozygous complement deficiencies often do not lead to an increased risk for infections. Therefore, most complement deficiencies are rare, but there are some exceptions, such as X-linked properdin deficiency and autosomal dominant $\mathrm{C} 1$-inhibitor deficiency [1]. Homozygous complement deficiencies can result in increased risk of infections. The frequency of these mutations is low, but prevalence differs in populations of different ethnic background [1].

Patients with CP deficiency have an increased susceptibility for S. pneumoniae infections. For instance, patients with mutations in $\mathrm{C} 1 \mathrm{q} / \mathrm{C} 1 \mathrm{r} / \mathrm{C} 1 \mathrm{~s}$, important for pathogen opsonization, are at an increased risk of infection with bacterial pathogens including $S$. pneumoniae [53]. The majority of patients with a homozygous C2 deficiency suffer from infections with S. pneumoniae [54], and C4-deficient patients have an increased risk of infection by S. pneumoniae as well.

Patients with LP deficiencies can also have increased susceptibility to infections with $S$. pneumoniae. In animal models, ficolin- and MASP-2-deficient mice are more susceptible for S. pneumoniae infections $[55,56]$. However, ficolin deficiencies in humans seem not directly associated with increased susceptibility for $S$. pneumoniae infections [57], but the occurrence of invasive pneumococcal disease was confirmed in patients with MASP-2 deficiencies.

Patients with AP deficiencies have a markedly increased risk for meningococcal infections, but invasive pneumococcal infections are also observed. The first patient with an AP complement deficiency was a patient with a properdin deficiency and fulminant meningococcal disease [58]. Patients who completely lack properdin have a 250 times higher incidence of invasive meningococcal infections compared to the general population [59]. Factor D-deficient patients have an increased risk for meningococcal and pneumococcal infections, likely because the speed of complement activation due to the lack of the AP amplification is lowered, giving the bacterial pathogens the ability to outgrow the clearance by the complement system [60-63].

All 3 activation pathways converge at the cleavage of $\mathrm{C} 3$ into anaphylatoxin $\mathrm{C} 3 \mathrm{a}$ and $\mathrm{C} 3 \mathrm{~b}$, which is deposited on the bacterial surface. C3 deficiency can be caused ei-

Common Genetic Variants in the

Complement System

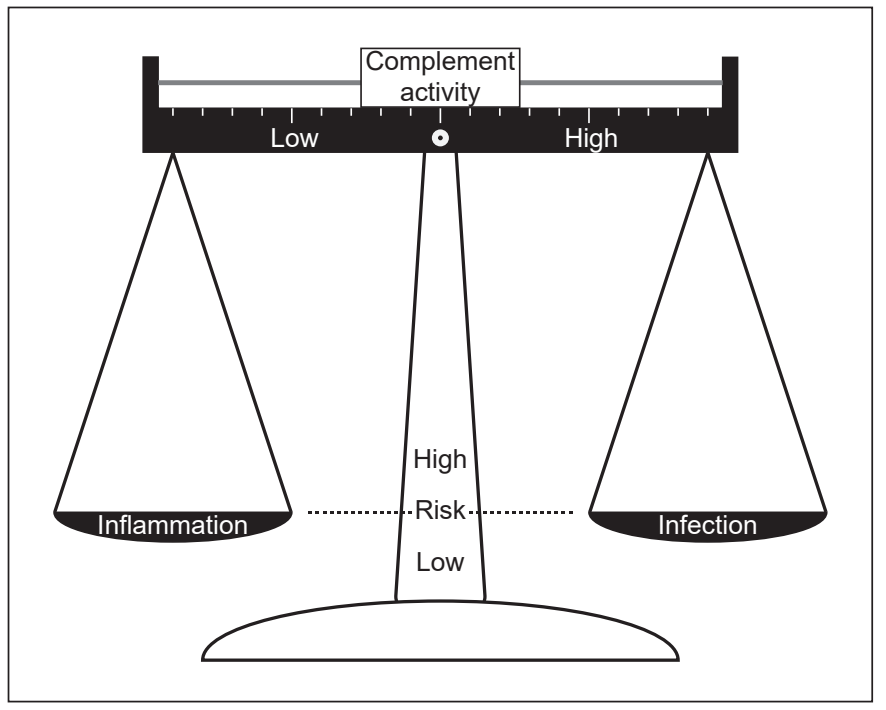

Fig. 3. Effect of complement activity on risk for inflammatory disorders and risk for infections.

ther by a polymorphism in the C3 gene itself or by a polymorphism in factor $\mathrm{H}$ or factor $\mathrm{I}$, which are regulators of the AP, leading to unregulated complement activation and consumption of $\mathrm{C} 3$ resulting in a secondary $\mathrm{C} 3$ deficiency [64]. Deficiency of C3 is associated with recurrent infections by many bacterial pathogens including S. pneumoniae [64].

Meningococcal infections are especially seen in patients with mutations in their TP such as $\mathrm{C} 6, \mathrm{C} 7$, and $\mathrm{C} 8$ [65]. In the case of C9 deficiency, the increase in susceptibility is far less than the other TP deficiencies. Despite C9 deficiency, the C5b-8 is still able to form a complex that gives some lysing activity, albeit this was 100-fold slower than normal human serum [1].

\section{Common Genetic Variants and Susceptibility to Bacterial Infections}

Rare genetic variants in many complement factors clearly increase the risk for infections with $S$. pneumoniae or N. meningitidis. However, common SNPs and gene cluster deletions are also known to affect complement activity, albeit to a lesser extent than complement deficiencies. Changing the balance toward complement activation may be beneficial to combat pathogens such as $S$. pneumoniae and $N$. meningitidis, but this also increases risk for chronic inflammatory conditions (Fig. 3). 
SNPs related to an increased complement activation are more often seen as compared to SNPs associated with reduced complement activation. This indicates that from an evolutionary perspective, increased complement activity is driven by positive selective pressure, despite the fact that this will result in an increased risk for chronic inflammatory diseases [3]. A documented example of evolutionary selection was described several decades ago by de Vries et al. [66]. In the 19th century, Dutch immigrants to Surinam were soon after arrival afflicted by typhoid and yellow fever, diminishing their numbers to $60 \%$. The descendants of these survivors had a higher prevalence for active complement C3 allele, compared to the source Dutch population, showing evidence that pressure by infection resulted in selection of this infection-protective complement C3-variant [66].

Common genetic variants within the complement system are mainly identified by genome-wide association studies (GWAS), in which a patient cohort is compared with a healthy cohort to identify SNPs associated with disease. To date, no GWAS has been published on pneumococcal disease susceptibility. Therefore, we start with examples from GWAS studies aimed to identify SNPs associated with $N$. meningitidis disease susceptibility and a genetic association study between complement factor $\mathrm{H}$ polymorphism and S. pyogenes infections. Despite the increasing interest in the complement system in disease susceptibility, only very few common genetic variants are functionally characterized.

\section{Neisseria meningitidis}

In a large study performed in children with IMD, SNP rs 1065489 in factor $\mathrm{H}$ and SNP rs426736 in factor H-related 3 were associated with a higher chance to develop IMD [67]. In another study, Lorés-Motta et al. [68] performed a GWAS to identify common SNPs associated with complement activity. They measured systemic complement activity by C3d/C 3 for over 2000 serum samples from healthy individuals and patients with age-related macular degeneration (AMD) and performed a GWAS to identify SNPs associated with higher complement activity. SNP rs3753396 in factor H and SNP rs6685931 in factor H-related 4 were associated with increased systemic complement activity [68]. In earlier studies, SNP rs3753396 was found not only to be protective for meningococcal disease, but also to be associated with increased risk for AMD $[69,70]$, highlighting the balance between complement-mediated protection and chronic inflammation (Fig. 3). Next to common SNPs in factor H gene, complement factor $\mathrm{H}$ gene cluster deletions are also common. For instance, a haplotype carrying a deletion of fac- tor H-related 1 (CFHR1) and CFHR3 is present in $20 \%$ of individuals, but occurrence is lower in patients with $\mathrm{AMD}$, indicating that absence of this gene cluster is associated with a lower risk for the development for AMD [71]. Vice versa, deletion of CFHR1 and CFHR3 is associated with an increased risk for atypical hemolytic uremic syndrome (aHUS) [72]. However, no data regarding an association with deletion of CFHR 1 and CFHR3 and susceptibility for infections with $N$. meningitidis or other bacterial pathogens have been demonstrated to date.

\section{Streptococcus pyogenes}

One clear example where a common SNP affects complement activity is the $\mathrm{Y} 402 \mathrm{H}$ polymorphism in factor $\mathrm{H}$ [73-75]. Patients with a homozygous risk allele have a 7-fold higher chance of getting AMD.

In later studies, the factor $\mathrm{H} 402 \mathrm{H}$ variant was shown to be associated with increased group A streptococcal killing in blood due to reduced binding of the factor $\mathrm{H} 402 \mathrm{H}$ variant to the bacterial surface compared to factor $\mathrm{H} 402 \mathrm{Y}$ and that allele $402 \mathrm{H}$ is suggested to be associated with protection from erysipelas and streptococcal tonsillitis $[76,77]$. Whether this factor $\mathrm{H}$ variant has an effect on meningococcal complement evasion or association with disease susceptibility has thus far not been demonstrated.

\section{Streptococcus pneumoniae}

Common SNPs in complement genes may impact the risk on pneumococcal disease as well. In a GWAS study on patients with community-acquired bacterial meningitis, an SNP (rs17611) in C5 was linked to disease outcome of pneumococcal meningitis [78]. It was found that C5 can be cleaved by neutrophil elastase and that SNP rs 17611 in C5 increased cleavage of C 5 by 6 -fold in vitro, thereby lowering total C5 levels in blood [79].

Most SNPs identified to date affecting complement activity are not associated with infectious diseases but with AMD or aHUS $[80,81]$. There is an ongoing active debate whether a specific $S$. pneumoniae-induced form of HUS exists or not [82-84]. Pneumococcal HUS is diagnosed in $\sim 5 \%$ of HUS patients in which it is hypothesized that removal of sialic acid from cell surfaces by excreted S. pneumoniae neuramidases exposes the Thomsen-Friedenreich crytantigen ( $\mathrm{T}$-antigen) enabling preformed IgM antibodies to react and cause aggregation in thrombotic microagiopathy and aggregation in microcirculation. However, there is support for a role of complement SNPs in pneumococcal HUS. Five pneumococcal HUS cases were described, and in all patients, both rare and common genetic variants in complement genes were found [83]. These included comple- 
ment factor $\mathrm{H} \mathrm{Y} 402 \mathrm{H}$ and $\mathrm{E} 936 \mathrm{D}$, which were previously reported to be associated with meningococcal disease susceptibility [67], complement factor B rs12614 that was previously associated with AMD [85], a haplotype carrying a deletion of CFHR1 and CFHR3 [72], and aHUS risk haplotypes in complement factor $\mathrm{H} \mathrm{H} 3$ and MCPggaac $[86,87]$.

Therefore, we postulate that the genetic background predisposing to aHUS results in overactivation of the complement system upon infection with the pneumococcus and other pathogens. Thus, the aHUS-associated genetic variants in the complement system seem to result in an increased pneumococcal disease severity.

\section{Complotypes Associated with Increased Susceptibility to Bacterial Infections}

Besides examining single common SNPs, it is interesting to examine combinations of complement SNPs, also referred as the "complotype" [3]. The compound effects of multiple SNPs may have a larger functional effect on the complement pathway than the isolated effects of single SNPs. In 2012, Harris and co-workers showed that a combination of 3 common SNPs in complement factors C3 (rs2230199), B (rs641153), and H (rs800292) resulted in a 6-fold difference in complement activity [3]. This variation in the complement function is significant, and this compound effect deserves further study. A novel complotype composed of rs4151667 and rs641153 in factor B and rs800292 in factor $\mathrm{H}$ strongly associated with $\mathrm{AMD}$ and complement activation [88].

Another way an SNP can influence the effect of factor $\mathrm{H}$ is by changing the plasma level. We showed that a 2 -fold reduction in factor $\mathrm{H}$ in mice resulted in an almost 4-log decreased pneumococcal load in the blood [50]. These results were corroborated with human in vitro studies where a 2 -fold difference in factor $\mathrm{H}$ resulted in a 3 -fold difference in killing in a whole blood killing assay [50]. This study clearly showed a delicate balance in which human factor $\mathrm{H}$ levels can affect pneumococcal C3 opsonization and clearance.

The abovementioned complotypes and experiments have mainly focused on the AP. The complement system consists of $>40$ proteins, which potentially could harbor multiple SNPs influencing complement activity. Therefore, other factors in the complement cascade may contribute to the overall complement activity of an individual person, and thereby affecting not only disease susceptibility but also their predisposition for chronic inflammatory diseases.

Common Genetic Variants in the

Complement System

\section{Effects of Complement SNPs on Inflammatory Response and Disease Severity}

An effective inflammatory response is an important component of the host defense to bacterial infections. This is, for instance, illustrated clinically in patients with NEMO and IRAK-4 deficiency who have lowered initiation of the host inflammatory response and therefore increased risk of severe pneumococcal infection [89]. Differences in inflammatory responses have been shown to affect disease outcome. First, increased inflammation due to higher S. pneumoniae bacterial loads in the CSF is associated with increased mortality [90]. For N. meningitidis, even with similar bacterial loads, increased inflammation as measured by peripheral blood cytokine levels was associated with poor disease outcome [91], highlighting the importance of a balanced immune response.

Differences in complement activation also result in the differential release of anaphylatoxins and chemoattractants, such as C3a and C5a. The latter was found to be a prime factor in modulating costimulation of immune cells to release cytokines. Addition of recombinant $\mathrm{C} 5 \mathrm{a}$ to human peripheral PBMCs stimulated with TLR ligands enhances cytokine production, whereas C5a without TLR ligands has almost no effect [92]. In addition, it has been demonstrated that $\mathrm{C} 5 \mathrm{a}$ binding to its receptor, $\mathrm{C} 5 \mathrm{aR}$, modulates the inflammatory response induced by many bacterial pathogens [93-95]. Therefore, complement activation also contributes to the inflammatory response upon infection. We have shown that costimulation of TLRs with $S$. pneumoniae and $\mathrm{C} 5 \mathrm{aR}$ with $\mathrm{C} 5 \mathrm{a}$, released after complement activation, boosted cytokine release by PBMCs [51]. In this assay, we demonstrated that doubling the level of factor $\mathrm{H}$ in serum, but still within the normal population range [96], resulted in a 2- to 3 -fold decrease in cytokine production due to a decreased complement activation and C5a release [51].

Recently, Li et al. [97] showed that genetic variation in cellular immune genes can explain up to $50 \%$ of the variability in cytokine levels, irrespectively of complement activity. These authors suggest that there are genetic variations that may strongly regulate cytokine production in response to certain pathogens. Furthermore, their results imply that monocyte-derived cytokine quantitative trait loci are associated with susceptibility to infections [97]. This shows that genetic variations throughout the immune system can be involved in regulation of the immune response and bacterial clearance. Experiments that combine genetic predisposition for complement activity and inflammatory responses as measured by cytokine

J Innate Immun 2020;12:131-141 137 
Fig. 4. Complement as a double-edged sword: effects of SNPs in complement factors on immunity.

SNPs resulting in increased complement activation

- rs2230199;C3 ${ }_{\text {R102G }}$

- rs4151667; factor B

- rs3753396; factor $\mathrm{H}$

- rs6685931; CFHR-4

Increased

- C3b opsonisation

- MAC formation and bacterial lysis

- Opsonophagocytosis

- Leukocyte activation

Advantage

- Increased leukocyte activation

- Increased cytokine production

- Increased pathogen clearance

Disadvantage

- Increased risk of inflammatory diseases (e.g. AMD)

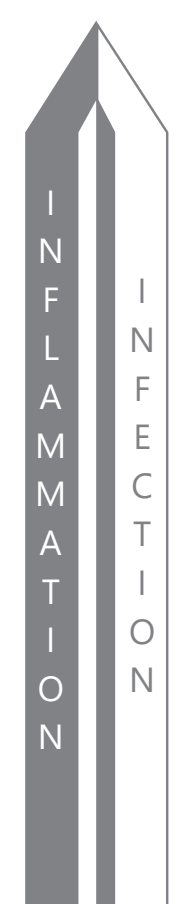

SNPs resulting in decreased complement activation

- rs800292; factor $\mathrm{H}_{\mathrm{V} 621}$

- rs17611; C5

- rs6411533; factor $B_{R 320}$

- rs1065489; factor $\mathrm{H}_{936 \mathrm{E}}$

- rs426736; CFHR-3

Decreased

- C3b opsonisation

- MAC formation and bacterial lysis

- Opsonophagocytosis

- Leukocyte activation

Advantage

- Less inflammation

- Decreased risk of inflammatory diseases (AMD)

\section{Disadvantage}

- Increased risk of infection

- Less pathogen clearance

- Increased risk of autoimmune diseases (e.g. SLE)

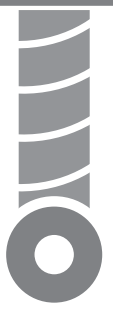

production by immune cells are a current focus of our research.

\section{Conclusion}

Complement deficiencies clearly increase disease susceptibility and outcome of both Gram-positive bacteria (e.g. S. pneumoniae and S. pyogenes) and Gram-negative bacteria (N. meningitidis) infections, but more recent data also support a potential link with common SNPs in genes coding for complement proteins and disease susceptibility. The compound effect of multiple complement polymorphisms, also called the complotype, may have a larger functional effect on complement pathway activity than isolated polymorphisms alone. Differences in complement activity also influence the inflammatory response through the release of anaphylatoxin $\mathrm{C} 3 \mathrm{a}$ and che- moattractant C5a. On top of that, genetic predisposition for increased inflammatory cytokine production may play an important role in disease outcome.

In summary, the complement system works like a double-edged sword (Fig. 4). It is a trade-off between protection against infectious diseases and enhanced inflammation. Ongoing studies of the complotype and genetic variation in cellular immune genes will further increase the insight in the factors that determine pneumococcal disease susceptibility and outcome.

\section{Statement of Ethics}

The authors have no ethical conflicts to disclose.

\section{Disclosure Statement}

The authors have no conflicts of interest to declare. 


\section{Funding Sources}

This review has received funding from the European Union's Horizon 2020 research and innovation program under grant agreement No. 668303.

\section{Author Contributions}

The authors declare that they have no conflict of interest.

\section{References}

1 Skattum L, van Deuren M, van der Poll T, Truedsson L. Complement deficiency states and associated infections. Mol Immunol. 2011 Aug;48(14):1643-55.

2 Hovingh ES, van den Broek B, Jongerius I; Hijacking Complement Regulatory Proteins for Bacterial Immune Evasion. Hijacking Complement Regulatory Proteins for Bacterial Immune Evasion. Front Microbiol. 2016 Dec;7: 2004.

3 Harris CL, Heurich M, Rodriguez de Cordoba $\mathrm{S}$, Morgan BP. The complotype: dictating risk for inflammation and infection. Trends Immunol. 2012 Oct;33(10):513-21.

4 Luna CM, Pulido L, Burgos D. Why is the rate of pneumococcal pneumonia declining? Curr Opin Pulm Med. 2018 May;24(3):205-11.

5 Henrichsen J. Six newly recognized types of Streptococcus pneumoniae. J Clin Microbiol. 1995 Oct;33(10):2759-62.

6 Deng X, Church D, Vanderkooi OG, Low DE, Pillai DR. Streptococcus pneumoniae infection: a Canadian perspective. Expert Rev Anti Infect Ther. 2013 Aug;11(8):781-91.

7 Bogaert D, van Belkum A, Sluijter M, Luijendijk A, de Groot R, Rümke HC, et al. Colonisation by Streptococcus pneumoniae and Staphylococcus aureus in healthy children. Lancet. 2004 Jun;363(9424):1871-2.

8 Simell B, Auranen K, Käyhty H, Goldblatt D, Dagan R, O’Brien KL; Pneumococcal Carriage Group. The fundamental link between pneumococcal carriage and disease. Expert Rev Vaccines. 2012 Jul;11(7):841-55.

9 Balaji V, Thomas K, Joshi HH, Beall B. Increasing invasive disease due to penicillin resistant S. pneumoniae in India. Indian J Med Sci. 2008 Dec;62(12):492-5.

10 Torres A, Blasi F, Peetermans WE, Viegi G, Welte T. The aetiology and antibiotic management of community-acquired pneumonia in adults in Europe: a literature review. Eur J Clin Microbiol Infect Dis. 2014 Jul;33(7): 1065-79.

11 Jacobs MR, Felmingham D, Appelbaum PC, Grüneberg RN; Alexander Project Group. The Alexander Project 1998-2000: susceptibility of pathogens isolated from communityacquired respiratory tract infection to commonly used antimicrobial agents. J Antimicrob Chemother. 2003 Aug;52(2):229-46.

12 Ren B, Szalai AJ, Hollingshead SK, Briles DE. Effects of PspA and antibodies to PspA on activation and deposition of complement on the pneumococcal surface. Infect Immun. 2004 Jan;72(1):114-22.
13 Harrison LH, Trotter CL, Ramsay ME. Global epidemiology of meningococcal disease. Vaccine. 2009 Jun;27(Suppl 2):B51-63.

14 Pizza M, Rappuoli R. Neisseria meningitidis: pathogenesis and immunity. Curr Opin Microbiol. 2015 Feb;23:68-72.

15 Meyer SA, Kristiansen PA. Household transmission of Neisseria meningitidis in the meningitis belt. Lancet Glob Health. 2016 Dec; 4(12):e885-6.

16 Schneider MC, Exley RM, Ram S, Sim RB, Tang CM. Interactions between Neisseria meningitidis and the complement system. Trends Microbiol. 2007 May;15(5):233-40.

17 Toneatto D, Pizza M, Masignani V, Rappuoli $R$. Emerging experience with meningococcal serogroup B protein vaccines. Expert Rev Vaccines. 2017 May;16(5):433-51.

18 Borrow R, Balmer P, Miller E. Meningococcal surrogates of protection-serum bactericidal antibody activity. Vaccine. 2005 Mar;23(1718):2222-7.

19 Giuntini S, Reason DC, Granoff DM. Combined roles of human IgG subclass, alternative complement pathway activation, and epitope density in the bactericidal activity of antibodies to meningococcal factor $\mathrm{h}$ binding protein. Infect Immun. 2012 Jan;80(1):187-94.

20 Andre GO, Converso TR, Politano WR, Ferraz LF, Ribeiro ML, Leite LC, et al. Role of Streptococcus pneumoniae Proteins in Evasion of Complement-Mediated Immunity. Front Microbiol. 2017 Feb;8:224.

21 Hyams C, Camberlein E, Cohen JM, Bax K, Brown JS. The Streptococcus pneumoniae capsule inhibits complement activity and neutrophil phagocytosis by multiple mechanisms. Infect Immun. 2010 Feb;78(2):704-15.

22 Dieudonné-Vatran A, Krentz S, Blom AM, Meri S, Henriques-Normark B, Riesbeck K, et al. Clinical isolates of Streptococcus pneumoniae bind the complement inhibitor C4bbinding protein in a $\mathrm{PspC}$ allele-dependent fashion. J Immunol. 2009 Jun;182(12):786577.

23 Dave S, Brooks-Walter A, Pangburn MK, McDaniel LS. PspC, a pneumococcal surface protein, binds human factor $\mathrm{H}$. Infect Immun. 2001 May;69(5):3435-7.

24 van der Maten E, van den Broek B, de Jonge MI, Rensen KJ, Eleveld MJ, Zomer AL, et al. Streptococcus pneumoniae PspC Subgroup Prevalence in Invasive Disease and Differences in Contribution to Complement Evasion. Infect Immun. 2018 Mar;86(4):e0001018.
25 Mukerji R, Mirza S, Roche AM, Widener RW, Croney CM, Rhee DK, et al. Pneumococcal surface protein A inhibits complement deposition on the pneumococcal surface by competing with the binding of C-reactive protein to cell-surface phosphocholine. J Immunol. 2012 Dec;189(11): 5327-35.

$26 \mathrm{Tu}$ AH, Fulgham RL, McCrory MA, Briles DE, Szalai AJ. Pneumococcal surface protein A inhibits complement activation by Streptococcus pneumoniae. Infect Immun. 1999 Sep;67(9): $4720-4$.

27 Mitchell TJ, Andrew PW, Saunders FK, Smith AN, Boulnois GJ. Complement activation and antibody binding by pneumolysin via a region of the toxin homologous to a human acute-phase protein. Mol Microbiol. 1991 Aug;5(8):1883-8.

28 Paton JC, Rowan-Kelly B, Ferrante A. Activation of human complement by the pneumococcal toxin pneumolysin. Infect Immun. 1984 Mar;43(3):1085-7.

29 Agarwal V, Kuchipudi A, Fulde M, Riesbeck K, Bergmann S, Blom AM. Streptococcus pneumoniae endopeptidase $\mathrm{O}$ (PepO) is a multifunctional plasminogen- and fibronectin-binding protein, facilitating evasion of innate immunity and invasion of host cells. J Biol Chem. 2013 Mar;288(10):6849-63.

30 Agarwal V, Hammerschmidt S, Malm S, Bergmann S, Riesbeck K, Blom AM. Enolase of Streptococcus pneumoniae binds human complement inhibitor C4b-binding protein and contributes to complement evasion. J Immunol. 2012 Oct;189(7):3575-84.

31 Terrasse R, Tacnet-Delorme P, Moriscot C, Pérard J, Schoehn G, Vernet T, et al. Human and pneumococcal cell surface glyceraldehyde3-phosphate dehydrogenase (GAPDH) proteins are both ligands of human Clq protein. J Biol Chem. 2012 Dec;287(51):42620-33.

32 Blom AM, Bergmann S, Fulde M, Riesbeck K, Agarwal V. Streptococcus pneumoniae phosphoglycerate kinase is a novel complement inhibitor affecting the membrane attack complex formation. J Biol Chem. 2014 Nov;289(47): 32499-511.

33 Mohan S, Hertweck C, Dudda A, Hammerschmidt S, Skerka C, Hallström T, et al. Tuf of Streptococcus pneumoniae is a surface displayed human complement regulator binding protein. Mol Immunol. 2014 Nov;62(1):249-64.

34 Schneider MC, Prosser BE, Caesar JJ, Kugelberg E, Li S, Zhang Q, et al. Neisseria meningitidis recruits factor $\mathrm{H}$ using protein mimicry of host carbohydrates. Nature. 2009 Apr;458(7240): 890-3. 
35 Lewis LA, Vu DM, Vasudhev S, Shaughnessy J, Granoff DM, Ram S. Factor H-dependent alternative pathway inhibition mediated by porin $\mathrm{B}$ contributes to virulence of Neisseria meningitidis. MBio. 2013 Oct;4(5):e00339-13.

36 Jarva H, Ram S, Vogel U, Blom AM, Meri S. Binding of the complement inhibitor C4bp to serogroup B Neisseria meningitidis. J Immunol. 2005 May; 174(10):6299-307.

37 Del Tordello E, Vacca I, Ram S, Rappuoli R, Serruto D. Neisseria meningitidis NalP cleaves human complement C3, facilitating degradation of $\mathrm{C} 3 \mathrm{~b}$ and survival in human serum. Proc Natl Acad Sci USA. 2014 Jan; 111(1):427-32.

38 Griffiths NJ, Hill DJ, Borodina E, Sessions RB, Devos NI, Feron CM, et al. Meningococcal surface fibril (Msf) binds to activated vitronectin and inhibits the terminal complement pathway to increase serum resistance. Mol Microbiol. 2011 Dec;82(5):1129-49.

39 Sa E Cunha C, Griffiths NJ, Virji M. Neisseria meningitidis Opc invasin binds to the sulphated tyrosines of activated vitronectin to attach to and invade human brain endothelial cells. PLoS Pathog. 2010 May;6(5):e1000911.

40 Merle NS, Church SE, Fremeaux-Bacchi V, Roumenina LT. Complement System Part I Molecular Mechanisms of Activation and Regulation. Front Immunol. 2015 Jun;6:262.

41 Gaboriaud C, Thielens NM, Gregory LA, Rossi V, Fontecilla-Camps JC, Arlaud GJ. Structure and activation of the $\mathrm{C} 1$ complex of complement: unraveling the puzzle. Trends Immunol. 2004 Jul;25(7):368-73.

42 Holmskov U, Thiel S, Jensenius JC. Collections and ficolins: humoral lectins of the innate immune defense. Annu Rev Immunol. 2003;21(1):547-78.

43 Hansen S, Selman L, Palaniyar N, Ziegler K, Brandt J, Kliem A, et al. Collectin 11 (CL-11, CL-K1) is a MASP-1/3-associated plasma collectin with microbial-binding activity. J Immunol. 2010 Nov;185(10):6096-104.

44 Forneris F, Ricklin D, Wu J, Tzekou A, Wallace RS, Lambris JD, et al. Structures of C3b in complex with factors $B$ and $D$ give insight into complement convertase formation. Science. 2010 Dec;330(6012):1816-20.

45 Janeway CA Jr, Medzhitov R. Innate immune recognition. Annu Rev Immunol. 2002;20(1): 197-216.

46 Botos I, Segal DM, Davies DR. The structural biology of Toll-like receptors. Structure. 2011 Apr;19(4):447-59.

47 Malley R, Henneke P, Morse SC, Cieslewicz MJ, Lipsitch M, Thompson CM, et al. Recognition of pneumolysin by Toll-like receptor 4 confers resistance to pneumococcal infection. Proc Natl Acad Sci USA. 2003 Feb;100(4) 1966-71.

48 Yoshimura A, Lien E, Ingalls RR, Tuomanen E, Dziarski R, Golenbock D. Cutting edge: recognition of Gram-positive bacterial cell wall components by the innate immune system occurs via Toll-like receptor 2. J Immunol. 1999 Jul;163(1):1-5.
49 Merle NS, Noe R, Halbwachs-Mecarelli L, Fremeaux-Bacchi V, Roumenina LT. Complement System Part II: role in Immunity. Front Immunol. 2015 May;6:257.

50 van der Maten E, Westra D, van Selm S, Langereis JD, Bootsma HJ, van Opzeeland FJ, et al. Complement Factor H Serum Levels Determine Resistance to Pneumococcal Invasive Disease. J Infect Dis. 2016 Jun;213(11):1820-7.

51 van der Maten E, de Bont CM, de Groot R, de Jonge MI, Langereis JD, van der Flier M. Alternative pathway regulation by factor $\mathrm{H}$ modulates Streptococcus pneumoniae induced proinflammatory cytokine responses by decreasing C5a receptor crosstalk. Cytokine. 2016 Dec;88:281-6.

52 Goicoechea de Jorge E, López Lera A, BayarriOlmos R, Yebenes H, Lopez-Trascasa M, Rodríguez de Córdoba S. Common and rare genetic variants of complement components in human disease. Mol Immunol. 2018 Oct;102: 42-57.

53 Pettigrew HD, Teuber SS, Gershwin ME. Clinical significance of complement deficiencies. Ann N Y Acad Sci. 2009 Sep;1173(1): $108-23$.

54 Jönsson G, Truedsson L, Sturfelt G, Oxelius VA, Braconier JH, Sjöholm AG. Hereditary C2 deficiency in Sweden: frequent occurrence of invasive infection, atherosclerosis, and rheumatic disease. Medicine (Baltimore). 2005 Jan;84(1):23-34.

55 Ali YM, Lynch NJ, Haleem KS, Fujita T, Endo Y, Hansen S, et al. The lectin pathway of complement activation is a critical component of the innate immune response to pneumococcal infection. PLoS Pathog. 2012;8(7): e1002793.

56 Endo Y, Takahashi M, Iwaki D, Ishida Y, Nakazawa N, Kodama T, et al. Mice deficient in ficolin, a lectin complement pathway recognition molecule, are susceptible to Streptococcus pneumoniae infection. J Immunol. 2012 Dec;189(12):5860-6.

57 Michalski M, Świerzko AS, Pągowska-Klimek I, Niemir ZI, Mazerant K, Domżalska-Popadiuk I, et al. Primary Ficolin-3 deficiency-is it associated with increased susceptibility to infections? Immunobiology. 2015 Jun;220(6): 711-3.

58 Sjöholm AG, Braconier JH, Söderström C. Properdin deficiency in a family with fulminant meningococcal infections. Clin Exp Immunol. 1982 Nov;50(2):291-7.

59 Fijen CA, Kuijper EJ, te Bulte MT, Daha MR, Dankert J. Assessment of complement deficiency in patients with meningococcal disease in The Netherlands. Clin Infect Dis. 1999 Jan; 28(1):98-105.

60 Weiss SJ, Ahmed AE, Bonagura VR. Complement factor $D$ deficiency in an infant first seen with pneumococcal neonatal sepsis. I Allergy Clin Immunol. 1998 Dec;102(6 Pt 1):1043-4.

61 Ram S, Lewis LA, Rice PA. Infections of people with complement deficiencies and patients who have undergone splenectomy. Clin Microbiol Rev. 2010 Oct;23(4):740-80.
62 Biesma DH, Hannema AJ, van Velzen-Blad $\mathrm{H}$, Mulder L, van Zwieten R, Kluijt I, et al. A family with complement factor $\mathrm{D}$ deficiency. J Clin Invest. 2001 Jul;108(2):233-40.

63 Sprong T, Roos D, Weemaes C, Neeleman C, Geesing CL, Mollnes TE, et al. Deficient alternative complement pathway activation due to factor D deficiency by 2 novel mutations in the complement factor $D$ gene in a family with meningococcal infections. Blood. 2006 Jun: 107(12):4865-70.

64 S Reis E, Falcão DA, Isaac L. Clinical aspects and molecular basis of primary deficiencies of complement component $\mathrm{C} 3$ and its regulatory proteins factor I and factor $\mathrm{H}$. Scand J Immunol. 2006 Mar;63(3):155-68.

65 Petersen BH, Lee TJ, Snyderman R, Brooks GF. Neisseria meningitidis and Neisseria gonorrhoeae bacteremia associated with C6, C7, or C8 deficiency. Ann Intern Med. 1979 Jun; 90(6):917-20.

66 de Vries RR, Meera Khan P, Bernini LF, van Loghem E, van Rood JJ. Genetic control of survival in epidemics. J Immunogenet. 1979 Aug;6(4):271-87.

67 Davila S, Wright VJ, Khor CC, Sim KS, Binder A, Breunis WB, et al.; International Meningococcal Genetics Consortium. Genomewide association study identifies variants in the $\mathrm{CFH}$ region associated with host susceptibility to meningococcal disease. Nat Genet. 2010 Sep;42(9):772-6.

68 Lorés-Motta L, Paun CC, Corominas J, Pauper M, Geerlings MJ, Altay L, et al. Genome-Wide Association Study Reveals Variants in CFH and CFHR4 Associated with Systemic Complement Activation: Implications in Age-Related Macular Degeneration. Ophthalmology. 2018 Jul;125(7): 1064-74.

69 Ng TK, Chen LJ, Liu DT, Tam PO, Chan WM, Liu K, et al. Multiple gene polymorphisms in the complement factor $\mathrm{h}$ gene are associated with exudative age-related macular degeneration in chinese. Invest Ophthalmol Vis Sci. 2008 Aug;49(8):3312-7.

70 Martinón-Torres F, Png E, Khor CC, Davila S, Wright VJ, Sim KS, et al.; ESIGEM network; ESPID meningococcal consortium - UK; EUCLIDS consortium members - Imperial College London (www.euclids-project.eu). Natural resistance to Meningococcal Disease related to $\mathrm{CFH}$ loci: meta-analysis of genome-wide association studies. Sci Rep. 2016 Nov;6(1):35842.

71 Hughes AE, Orr N, Esfandiary H, Diaz-Torres M, Goodship T, Chakravarthy U. A common CFH haplotype, with deletion of CFHR1 and CFHR3, is associated with lower risk of age-related macular degeneration. Nat Genet. 2006 Oct;38(10):1173-7.

72 Zipfel PF, Edey M, Heinen S, Józsi M, Richter H, Misselwitz J, et al. Deletion of complement factor H-related genes CFHR1 and CFHR3 is associated with atypical hemolytic uremic syndrome. PLoS Genet. 2007 Mar; 3(3):e41. 
73 Klein RJ, Zeiss C, Chew EY, Tsai JY, Sackler RS, Haynes C, et al. Complement factor $\mathrm{H}$ polymorphism in age-related macular degeneration. Science. 2005 Apr;308(5720):385-9.

74 Edwards AO, Ritter R 3rd, Abel KJ, Manning A, Panhuysen C, Farrer LA. Complement factor $\mathrm{H}$ polymorphism and age-related macular degeneration. Science. 2005 Apr;308(5720): 421-4.

75 Haines JL, Hauser MA, Schmidt S, Scott WK, Olson LM, Gallins P, et al. Complement factor $\mathrm{H}$ variant increases the risk of age-related macular degeneration. Science. 2005 Apr; 308(5720):419-21.

76 Haapasalo K, Jarva H, Siljander T, Tewodros W, Vuopio-Varkila J, Jokiranta TS. Complement factor $\mathrm{H}$ allotype $402 \mathrm{H}$ is associated with increased C3b opsonization and phagocytosis of Streptococcus pyogenes. $\mathrm{Mol} \mathrm{Mi}$ crobiol. 2008 Nov;70(3):583-94.

77 Haapasalo K, Vuopio J, Syrjänen J, Suvilehto J, Massinen S, Karppelin M, et al. Acquisition of complement factor $\mathrm{H}$ is important for pathogenesis of Streptococcus pyogenes infections: evidence from bacterial in vitro survival and human genetic association. J Immunol. 2012 Jan;188(1):426-35.

78 Woehrl B, Brouwer MC, Murr C, Heckenberg SG, Baas F, Pfister HW, et al. Complement component 5 contributes to poor disease outcome in humans and mice with pneumococcal meningitis. J Clin Invest. 2011 Oct; 121(10):3943-53.

79 Giles JL, Choy E, van den Berg C, Morgan BP, Harris CL. Functional analysis of a complement polymorphism (rs17611) associated with rheumatoid arthritis. J Immunol. 2015 Apr;194(7):3029-34.

80 Geerlings MJ, de Jong EK, den Hollander AI. The complement system in age-related macular degeneration: A review of rare genetic variants and implications for personalized treatment. Mol Immunol. 2017 Apr;84:6576.
81 Kavanagh D, Goodship T. Genetics and complement in atypical HUS. Pediatr Nephrol. 2010 Dec;25(12):2431-42.

82 Cody EM, Dixon BP. Hemolytic Uremic Syndrome. Pediatr Clin North Am. 2019 Feb; 66(1):235-46.

83 Szilágyi A, Kiss N, Bereczki C, Tálosi G, Rácz $\mathrm{K}$, Túri $\mathrm{S}$, et al. The role of complement in Streptococcus pneumoniae-associated haemolytic uraemic syndrome. Nephrol Dial Transplant. 2013 Sep;28(9):2237-45.

84 Pettigrew MM, Fennie KP, York MP, Daniels $J$, Ghaffar F. Variation in the presence of neuraminidase genes among Streptococcus pneumoniae isolates with identical sequence types. Infect Immun. 2006 Jun;74(6):3360-5.

85 Hughes AE. Complement factor B polymorphism $32 \mathrm{~W}$ protects against agerelated macular degeneration. 2011.

86 Caprioli J, Castelletti F, Bucchioni S, Bettinaglio P, Bresin E, Pianetti G, et al.; International Registry of Recurrent and Familial HUS/ TTP. Complement factor $\mathrm{H}$ mutations and gene polymorphisms in haemolytic uraemic syndrome: the C-257T, the A2089G and the G2881T polymorphisms are strongly associated with the disease. Hum Mol Genet. 2003 Dec;12(24):3385-95.

87 Marini SC, Gomes M, Guilherme R, Carda JP, Pinto CS, Fidalgo T, et al. Atypical hemolyticuremic syndrome: recurrent phenotypic expression of a patient with MCP gene mutation combined with risk haplotypes. Blood Coagul Fibrinolysis. 2019 Mar;30(2):68-70.

88 Paun CC, Lechanteur YT, Groenewoud JM, Altay L, Schick T, Daha MR, et al. A Novel Complotype Combination Associates with Age-Related Macular Degeneration and High Complement Activation Levels in vivo. Sci Rep. 2016 May;6(1):26568.

89 Picard C, Puel A, Bustamante J, Ku CL, Casanova JL. Primary immunodeficiencies associated with pneumococcal disease. Curr Opin Allergy Clin Immunol. 2003 Dec;3(6):451-9.
90 Giampaolo C, Scheld M, Boyd J, Savory J, Sande M, Wills M. Leukocyte and bacterial interrelationships in experimental meningitis. Ann Neurol. 1981 Apr;9(4):328-33.

91 Westendorp RG, Langermans JA, Huizinga TW, Verweij CL, Sturk A. Genetic influence on cytokine production in meningococcal disease. Lancet. 1997 Jun;349(9069):1912-3.

92 Cheng SC, Sprong T, Joosten LA, van der Meer JW, Kullberg BJ, Hube B, et al. Complement plays a central role in Candida albicansinduced cytokine production by human PBMCs. Eur J Immunol. 2012 Apr;42(4):9931004.

93 Brekke OL, Christiansen D, Fure H, Pharo A, Fung M, Riesenfeld J, et al. Combined inhibition of complement and CD14 abolish E. coliinduced cytokine-, chemokine- and growth factor-synthesis in human whole blood. Mol Immunol. 2008 Aug;45(14):3804-13.

94 Skjeflo EW, Christiansen D, Espevik T, Nielsen EW, Mollnes TE. Combined inhibition of complement and CD14 efficiently attenuated the inflammatory response induced by Staphylococcus aureus in a human whole blood model. J Immunol. 2014 Mar;192(6): 2857-64.

95 Sprong T, Brandtzaeg P, Fung M, Pharo AM, Høiby EA, Michaelsen TE, et al. Inhibition of C5a-induced inflammation with preserved C5b-9-mediated bactericidal activity in a human whole blood model of meningococcal sepsis. Blood. 2003 Nov; 102(10):3702-10.

96 Haralambous E, Dolly SO, Hibberd ML, Litt DJ, Udalova IA, O'dwyer C, et al. Factor $\mathrm{H}$, a regulator of complement activity, is a major determinant of meningococcal disease susceptibility in UK Caucasian patients. Scand J Infect Dis. 2006;38(9):764-71.

97 Li Y, Oosting M, Smeekens SP, Jaeger M, Aguirre-Gamboa R, Le KTT, et al. A Functional Genomics Approach to Understand Variation in Cytokine Production in $\mathrm{Hu}$ mans. Cell. 2016 Nov 3;167(4):1099-110.e14. 